\title{
Water Value Flows Upstream
}

\author{
Hubert H. G. Savenije ${ }^{1}$ and Pieter van der Zaag $1,2, * \mathbb{C}$ \\ 1 Water Management Department, Delft University of Technology, 2628 CN Delft, The Netherlands; \\ h.h.g.savenije@tudelft.nl \\ 2 Land and Water Management Department, IHE Delft, 2611 AX Delft, The Netherlands \\ * Correspondence: p.vanderzaag@un-ihe.org
}

Received: 4 August 2020; Accepted: 2 September 2020; Published: 22 September 2020

\begin{abstract}
Arjen Hoekstra postulated in 2001 that the value of water accumulates in an upstream direction: water value flows upstream. The ultimate source of this value is the rain. This original idea he used to develop the water value-flow concept. This article shows that the water value-flow concept has much to offer in terms of contemporary challenges. It is fully consistent with the "Five Bellagio Principles on Valuing Water" that the High Level Panel of Water published in 2017, and can make significant contributions to the first four principles. This article also shows that the concept can make many more contributions, including incorporating precipitationsheds, and thus include the source areas of rainfall in valuing water. Yet, until now, this innovative and potentially ground breaking concept has been largely ignored by researchers and practitioners in the fields of water resources management and economics. We conclude that the value-flow concept is a unique and promising framework for the integrated assessment of the value of water within a water resources system or river basin. We suggest that the concept can be enriched by incorporating instream benefits, water quality, as well as social, cultural, and spiritual values. We also suggest to test whether the concept can be usefully applied, and add value, to the emerging fields of socio-hydrology and water accounting.
\end{abstract}

Keywords: valuation; integrated assessment; water economics; water resources management

\section{Introduction}

Here, consistent with the work of Arjen Hoekstra, it is postulated that the value of water accumulates in an upstream direction: water value flows upstream. The ultimate source of this value is the rain. However, how can value be attributed to rainfall? The value of water has during the last few years received increasing attention, mainly through the work of the High Level Panel of Water, which published in 2017 the "Five Bellagio Principles on Valuing Water" (see https://sustainabledevelopment.un.org/content/documents/15591Bellagio_principles_on_valuing_ water_final_version_in_word.pdf; last visited 31 May 2020). These principles suggest that if policy-makers and society at large are aware of the multiple values of water, including the non-economic values such as spiritual, ecological, and social values, better decisions will be made.

As the concept of "value" has multiple meanings [1,2], first we clarify that in this paper we refer to the economic value, including those environmental values that can be quantified. These are thus "assigned values", values that individuals attach to specific physical goods, activities, or services [1,2].

Because virtually all human and ecosystem activities rely on the availability of water and because no economic activity is possible without it, it was internationally agreed during the International Conference on Water and Sustainable Development (held in Dublin in 1992) that water should be considered as an economic good. Since then, "Water as an Economic Good" became one of the most cited Dublin Principles. However, ever since the concept was launched, there has been confusion about what "water as an economic good" actually meant. Some interpreted it purely in financial and 
monetary terms, while others insisted that it essentially implies that decisions should be made on the basis of comprehensive weighing of societal costs and benefits [3,4]. The latter interpretation implies that economic decisions should be made on the basis of integrated valuation of water.

However, valuing water is not straightforward [5], not only due to water's physical, political, and economic characteristics [6], but also because of the difficulty or even impossibility to commensurate these different value dimensions into one metric $[7,8]$. However, there are other complicating aspects. One is that water is vital, finite, fugitive, and irreplaceable at the same time, but also because water use is part of a complex water resources system [9]. Moreover, water is both an economic and a public good as well as a common pool resource [4]. We do not know of any other good with this unique combination of features.

A further complicating aspect is that the hydrology of water creates upstream-downstream interdependencies between users, leading to what has been called water asymmetry: downstream water users often depend on what upstream users do, whereas most of the time upstream users are not or little impacted by what downstream users do, at least within the water realm [10]. This makes it necessary to take the water cycle into account when valuing it.

It has been argued that knowing the precise value—or values—of water may not be such a critical issue; but, rather that the process of valuing water should offer a structured and transparent mechanism to engage different stakeholders, who may value water differently [11]. Others insist that innovation in valuing water is, however, necessary [6]. Garrick and collaborators point at typical existing economic techniques that need to be improved, as well as the need to combine economic with cultural valuation techniques [6].

With Hoekstra, we would argue that what is certainly needed is to conceptualize the value of water in direct connection to the water cycle and the water resources system. Arjen Hoekstra was a pioneer in efforts to achieve this. Twenty years ago he introduced the value-flow concept [12-15], in the early days of integrated water resources management (IWRM) research. However, current water economics scholarship has ignored this concept, and not even criticized it.

This paper aims to revive the value-flow concept, by briefly reviewing it (Section 2), expanding it to include precipitationsheds (Section 3), considering its potential contribution to the new fields of socio-hydrology and water accounting (Section 4), exploring possible applications to contemporary water challenges (Section 5), and finally, as a way of conclusion, formulating some directions for future research (Section 6).

\section{The Water Value-Flow Concept: Water Values Flow Upstream}

In 2000, Arjen Hoekstra and his students became interested in the question how the value of water, as it is used in a particular place, is connected to the catchment that generated the water. Until then, the value of water was always considered merely in relation to the direct use of the water, but not to the system that produced it. As a hydrologist, one is used to considering a water system as an undividable unit where all components of the system are interconnected, consisting of several sources, stocks, and flows. Before the concept of IWRM became common practice, considering such sources in isolation had led to serious mistakes, where for instance a river dried up as a result of groundwater extractions or afforestation in its drainage basin. Not considering the hydrological connection between different water uses in relation to the water available in the entire system is a serious flaw in water resources management. The river basin is the natural system boundary for water systems, since all the water in a basin stems from the rain (or more correctly the precipitation) falling within its boundaries. Hence, the precipitation is the source of all the benefits accrued from the water. These benefits represent a value of the water. Ultimately the accumulation of all these values should be attributed to the rain. This, however, leads to a paradox, because most people would say that the rain is for free, and something that is for free has no value; however, all benefits obtained from using water within a catchment are derived from that same rainfall. Does the most valuable resource, the rain, have no value? ("Nothing is more useful than water; but it will purchase scarce anything; scarce anything 
can be had in exchange for it." (Adam Smith, 1776: 33; cited in [16])) This paradox stems from the mismatch between finance and economics. Finance is about what something costs or what one pays for it, but economics is about values and how to account for values in decision making. Another element of the paradox is that it is believed that rainfall is a given thing, either by god or by nature, and that humans cannot influence it. The latter is not entirely true, but that will be discussed later. However, if we agree that rainfall has value (without it almost no human or biological activity would be possible within a river basin), how can this value be established?

This fundamental question inspired Arjen Hoekstra and his group to start a report series (the Value of Water Research Report Series) (See https://waterfootprint.org/en/resources/publications/value-waterresearch-report-series-unesco-ihe; last visited on 31 May 2020; note that the first 10 publications can be found in the IHE Delft repository (https://ihedelftrepository.contentdm.oclc.org/), except \#1 and \#6, which could not be located) at IHE Delft, where he was then a lecturer. The first formal publication stemming from this initiative was published in 2001 as "An integrated approach towards assessing the value of water: A case study on the Zambezi basin" by Hoekstra and collaborators [13], in a relatively new journal Integrated Assessment. This first paper, that applied the theory of "Water Value-Flows" to the Zambezi river basin, postulated that the value of water in a river system accumulates in the upstream direction. It distinguished between the direct value of the water (DV), which is attributed locally by a user, and the indirect value (IV) coming from its downstream uses, and that is transferred upstream. The full value (FV) traveling upstream is the sum of the direct value of the local user plus the indirect value that the water already had accumulated from downstream uses. Building on that idea, they calculated the accumulated value of all the water uses in the Zambezi basin, and calculated the value of the rain falling over the basin.

More than 10 years later, Tilmant and collaborators [17] published an article on the water value in the Zambezi basin adopting a methodology that differed from the water value-flow concept as in [13]. Surprisingly, they came to the same conclusion that the value of water in the basin increases in the upstream direction (Figure 1). However, their findings also differed in detail from those of [13], which may be partly explained by that Tilmant et al. only considered blue water (i.e., water in rivers, lakes, and reservoirs), whereas Hoekstra et al. included green water (i.e., rainfall water that is used directly by ecosystems and rainfed agriculture for biomass production) in their analysis (see also Section 5.1 below).

(a)

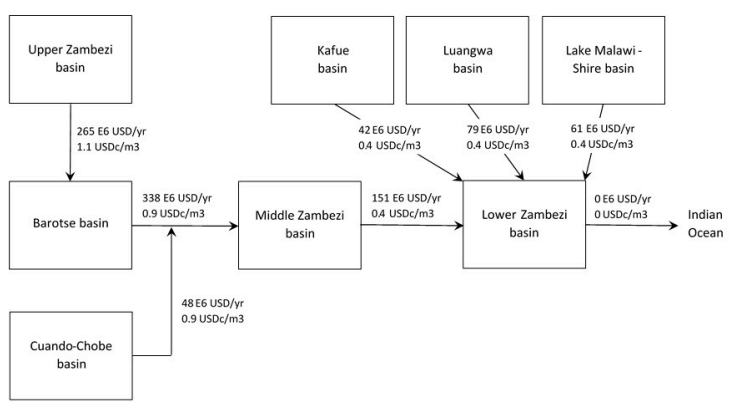

(b)

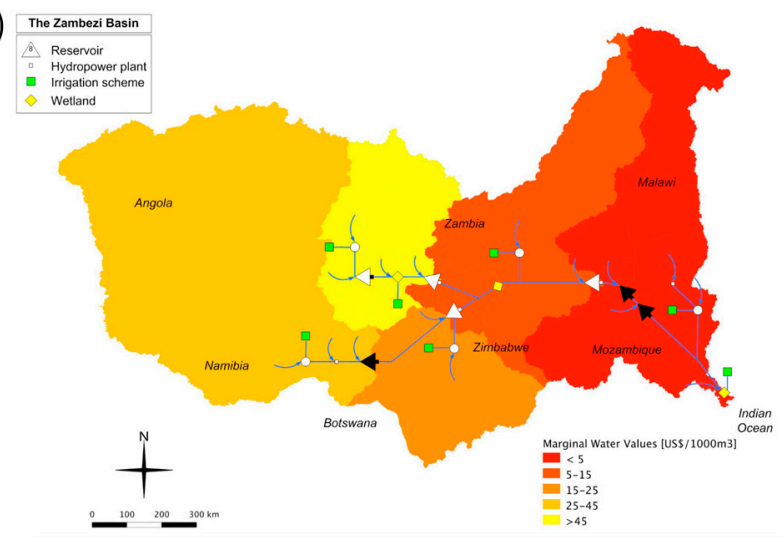

Figure 1. Estimates of the spatial distribution of the water value in the Zambezi basin: (a) total value (million US\$/yr) and average value per unit of river runoff (US\$ cents $/ \mathrm{m}^{3}$ ) per sub-basin in 1990 (source: Figure 6 in [13]); (b) projected future marginal water values (full development of hydropower and irrigation potential) (US\$/1000 $\mathrm{m}^{3}$ ) (source: Figure 6 in [17]).

Whereas this paper [13] was a first postulation of the concept with an initial sketch of how it could be applied to a particular river basin, it raised pertinent questions, "What is the value of rainwater, how does the value of river water increase if we move from downstream to upstream, what is the 
value of a return flow, and what are the opportunity costs if we withdraw water from a location for a particular use?" Until that time such questions had not been asked nor conceptualized consistently in a quantitative manner. They also formulated follow-up questions, "How to deal with the value of water used by ecosystems? How to value pollution as a disbenefit? How to value flood hazard or flood protection?"

One important issue was how to account for the temporal dynamics. The 2001 paper merely used annual average flows, but water resources and water demands are not constant over time. They fluctuate within the year and between years. Obviously water has a higher value during drought and a lower value, or even a cost, during floods. Hence, without accounting for the temporal dynamics, it is not possible to value water. In addition, water has a different utility depending on whether it flows in a river or is stored in a reservoir or aquifer. The water system consists of stocks (reservoirs, lakes, and aquifers) and fluxes (rivers, streams, and sources) which have different potential uses and values attributed to them. This triggered the development of a dynamic model, based on the dynamic water balance equation, which they presented in a paper entitled, "The water value-flow concept" [15]:

$$
\frac{\mathrm{d} S(t)}{\mathrm{d} x}=\sum_{i=1}^{m} Q_{i n, i}(t)-\sum_{j=1}^{n} Q_{o u t, j}(t)
$$

where $S$ is the storage (stock) of water $\left[\mathrm{L}^{3}\right], t$ is time $[\mathrm{T}], Q_{\mathrm{in}, i}$ is the inflow of stream $i$, and $Q_{\text {out }, j}$ is the outflow of stream $j$, both expressed in $\left[\mathrm{L}^{3} \mathrm{~T}^{-1}\right]$. Note that the storage increases over time as a result of the inflow and depletes as a result of the outflow. In Figure 2 this is explained in a conceptual sketch.

\begin{tabular}{|c|c|c|c|c|c|}
\hline Flow process & Balance co & mponents & & Balance equation & Residence time \\
\hline Water flow & $\stackrel{Q_{\text {in, } i}(t)}{\longrightarrow}$ & $\begin{array}{l}\text { Water } \\
\text { storage } \\
\text { (S) }\end{array}$ & $\stackrel{Q_{\text {out }, j}(t)}{\longrightarrow}$ & $\frac{\mathrm{dS}(t)}{\mathrm{dt}}=\sum_{i=1}^{m} Q_{\mathrm{in}, i}(t)-\sum_{j=1}^{n} Q_{\text {out }, j}(t)$ & $k_{w}(t)=\frac{S(t)}{\sum_{j=1}^{\prime} \text { Outs }_{j}(t)}$ \\
\hline Value flow & $I V Q_{i n, i}(t)$ & $\begin{array}{c}\text { Value of } \\
\text { stock } \\
F V S(t)\end{array}$ & $F V Q_{\text {out }, j}(t)$ & $\frac{\mathrm{dFV} S(t)}{\mathrm{dt}}=\sum_{j=1}^{n} \mathrm{FV} Q_{\text {out }, j}(t)-\sum_{i=1}^{m} \mathrm{IV} Q_{\mathrm{in}, i}(t)$ & $k_{v}(t)=\frac{S(t)}{\sum_{i=1}^{m} Q_{\operatorname{in} i}(t)}$ \\
\hline
\end{tabular}

Figure 2. Comparison of water flow and value-flow processes (source: [15]).

Similarly, the dynamic water value-flow equation was derived as

$$
\frac{\operatorname{dFVS}(t)}{\mathrm{d} t}=\sum_{j=1}^{n} \mathrm{FVQ}_{o u t, j}(t)-\sum_{i=1}^{m} \operatorname{IV} Q_{i n, i}(t)
$$

where FV $S$ is the full value of the stock (e.g., in $\$$ ), $F V Q_{\text {out, } j}$ is the full value of the outgoing flux $j\left(\$ \mathrm{~T}^{-1}\right)$ and IVQ $Q_{\mathrm{in}, i}$ is the indirect value of the inflowing stream $i\left(\$ \mathrm{~T}^{-1}\right)$. Note that in the water value-flow equation the inflow has a negative sign and the outflow is positive; the reverse of the water balance. Mathematically it means that water flows downstream, but the value of the water flows in the upstream direction (see Figure 2, from [15]).

A fascinating consequence of this approach was that, similar to input-output modelling in economics, this method allowed for the calculation of the water multiplier effect in water valuation. Return flows can be used several times, for instance as a result of return flows from irrigation works or from urban water supply, which can be used again downstream, or as a result of hydropower, where the turbined flow can be used again for other purposes downstream. An often disregarded type of reuse is that part of the water consumed by plants, and evaporated to the atmosphere, returns again to the river basin as rainfall and as such can be used again productively. This so-called moisture recycling causes a multiplier effect (or return rate) on rainfall [18-20], but also on the value of water. 
This effect was identified and calculated by Hoekstra and collaborators [13], and is further elaborated in Section 3.

Thus, the water value-flow concept was a significant advance on the contingent valuation approach described by Lockwood [1]. It is a unifying, integrating, approach, and not a tool for disaggregating the diversity of values along a river (for example), as Seymour and collaborators [2] have done. This water value-flow concept was pioneering, but as is mostly the case with such innovative ideas, it was largely neglected by the water resources management community (by 31 May 2020, [14] had been cited 11 times according to Scopus and 27 times according to Google Scholar; [15] had been cited 7 times according to Scopus and 24 times according to Google Scholar. Note that [13] does not appear in Scopus, and was cited 57 times according to Google Scholar). Why did this ground-breaking paper not resonate within the community? Answering that question is mostly speculation, but several factors may have contributed to this unfortunate situation. First of all, it is a misunderstanding that research communities appreciate innovative and unconventional papers. The best cited papers are normally the papers that build on generally accepted knowledge and approaches. Reasons for that may be conservativism, the not-invented-here syndrome, discomfort with thinking beyond the vested boundaries of one's discipline, but also vices, such as jealousy, protectionism, or disdain, "How can a hydrologist claim to know something about economics?" A weak consolation may be that there is nothing new in this regard. Alexander von Humboldt (1769-1859) observed that there are three stages in scientific discovery: first, people deny that it is true; then, they deny that it is important; and finally, they credit the wrong person [21]. However, maybe it is just because the journals that these papers were published in did not have a high enough impact factor to trigger attention, or that they did not reach the right audience to generate a larger response. We hope that this review paper will help to restore this injustice.

\section{From Rainfall to Precipitationsheds}

The popular belief is that all rainfall stems from evaporated seawater [18]. However, the global water balance teaches us that only $60 \%$ of the precipitation has a direct marine origin and that $40 \%$ stems from terrestrial evaporation [20]. Of all the terrestrial evaporation, about $60 \%$ returns again to the Earth's surface as precipitation. Large parts of the more arid regions of the world (eastern China, the Sahel, and the southern Amazon) rely to a very large extent on terrestrial sources [20]. Due to the general circulation of the atmosphere, moving eastward on the Northern and Southern Hemisphere and westward in the tropics, precipitation in East China depends largely on the evaporation in Europe, and precipitation in the Sahel depends largely on evaporation in the Great Lakes region in East Africa. Surprisingly, precipitation on the southern Amazon, Bolivia, and the Rio de la Plata basin relies to a very large extent on evaporation in the northern Amazon forest [20]. If the terrestrial evaporation is reduced by deforestation or land degradation, downwind areas can be largely affected, particularly during dry periods.

So, the well-established concept of a watershed that indicates the region within which rainfall drains to a given outfall of a river basin, should be complemented with the concept of precipitationshed, which identifies the region from which the precipitation originates [22]. Part of that region contains seas and oceans, but a substantial part may consist of land. This concept was introduced by Keys and collaborators [22] which would allow applying the water value-flow concept also to the source areas of the rainfall, and hence to allow valuing land and water conservation activities or ecosystem services in these regions. Obviously rainforests and ecosystems that maintain evaporation during periods when there is water scarcity downwind have a large value in sustaining precipitation and maintaining a higher humidity level in such vulnerable regions.

\section{The Water Value-Flow Concept and the New Fields of Socio-Hydrology and Water Accounting}

Recently, Sivapalan and collaborators [23] coined the field of socio-hydrology as the new science that integrates water resources management, economics, hydrology, and sociology. The key in this 
concept is the integration between these disciplines, which until recently was mostly lacking, whereby the different communities largely remained within their own comfort zone. However, for the complex issues of today, with drastic societal, climatic, economic, and ecological implications that are tightly interwoven, such an integrated theory is highly relevant. In addition there is a new discipline upcoming of water accounting [24], which aims to present the interdependency of water uses in quantitative terms at different scales, ranging from individual user systems to river systems, nations and continents. Finally, in 2013, the International Association of Hydrological Sciences (IAHS) launched the international science decade named Panta Rhei ("everything flows") on the interaction between water and society in an environment of change [25] where the value attributed by society to water is a key element. The value-flow concept discussed in this paper, could play a fundamental role within these concepts as a vehicle for integration.

\section{The Relevance of the Water Value-Flow for Contemporary Societal Challenges}

This section aims to demonstrate the relevance of the water value-flow concept for some of the urgent societal challenges. We focus on green water, with which most biomass on Earth is produced; on ecological values, which are increasingly being recognized as key to transforming our political economy into a sustainable one; and on water pollution and finally on the transboundary dimension.

\subsection{Green Water}

Much of the hydro-economic modelling exercises that have been published focus on irrigated agriculture while ignoring rainfed agriculture (for example, the special issue on "Integrated hydro-economic modelling" of the journal Ecological Economics contains four papers that include the agricultural sector, but all are limited to irrigated agriculture, and ignore rainfed agriculture (see [26])). After Malin Falkenmark introduced the "green water" concept in 1995 (see [27]), which emphasized the importance of rain water as a resource, Hoekstra could not ignore green water in applying this novel water value-flow concept to the Zambezi river basin, simply because the valuation process is integrated into a hydrological model [13]. He found that, in the Zambezi basin, rainfed agriculture used 50 times more green water than irrigated agriculture used green and blue water together, and that the production value of rainfed agriculture was 22 times larger than that of irrigated agriculture.

In sub-Saharan Africa, $90 \%$ of the food production is rainfed, and highly suboptimal [28]. Ironically, there is a great advantage hidden in the fact that yields are so low, because it implies there is a large potential to enhance agricultural productivity. Much research has been done into improving rainfed farming, whereby the highest benefits are obtained by reducing the vulnerability to dry spells and by bridging dry spells through moisture conservation and supplementary irrigation (e.g., [29,30]). Such interventions have additional-not minor-benefits in soil and water conservation, carbon sequestration, poverty alleviation, rural economic development, and enhanced moisture recycling [28], adding additional value to the rain.

\subsection{Ecosystem Service Values}

The logical step would now be to extend the water value-flow concept to include also biomassrelated ecosystem services, which also consume green water, and which provide critical benefits, not only to the ecological system, but also to the socio-economic system.

The water value-flow concept could then assess which interventions will enhance the total value of the system, and who would bear the costs of these measures and who would reap the benefits. This would allow smart deals to be established, for example in the form of providing compensation to land use managers (such as farmers), who through soil and water conservation measures, may enhance the base flow and reduce sediment loads or flood flows somewhere downstream, likewise the payment for environmental services (PES) concept [31].

However, ecological values in river basins extend beyond the consumptive uses of water, as some rely on instream flows and on particular flow regimes and dynamics. These particular values pose an 
interesting challenge; for these it is impossible to attribute a certain volume of water to a particular value, as the dose-response relation is complex and largely non-consumptive. Consider a certain river flow that produces benefits, e.g., it allows for the spawning of certain fish species during a particular season and at a particular place, which later on in their life cycle generates tangible ecological, social, and economic benefits. This same river flow is likely to generate other (instream) benefits in other stretches of the river as well. To make the story even more complex, such values may only materialize if at the same site in a different season another (higher or lower) flow occurs. This means that the occurrence of certain flow regimes need to be attributed value, i.e., a certain minimum high flow during the wet season and a certain minimum and maximum flow during the dry season. This also implies that it is impossible to attribute such an ecological value to any particular volume of water (see [32]). This certainly poses a huge challenge to the water value-flow concept (and any other economic concept that attributes value to absolute volumes of river water), and we invite scholars to explore ways to incorporate such non-consumptive and instream water values in this novel concept.

\subsection{Water Quality; and the Silt Loads of the Blue Nile}

The water value-flow concept in principle also can include, parallel to the water flows, a track of pollutant flows from source to sinks, and the costs and (sometimes in rare occasions) benefits these generate. These can then be included in the value-flow.

This is particularly relevant in, for example, the case of the Blue Nile, where the biggest water quality issue concerns the sediment loads in river water during the flood season. Whereas in the period 1925-1938, the average maximum silt concentration entering Gezira irrigation scheme in Sudan was about 1000 ppm, during the period 2003-2006, it frequently exceeded 10,000 ppm [33]. In the early days of the Gezira scheme these silt loads were beneficial as they acted as a kind of fertilizer. However, the current excessive concentrations silt-up reservoirs and clog irrigation canals, leading to costly measures to mitigate these problems [34-36]. The explanation of how this massive increase in silt-load occurred is complex [33,37], but it is evident that the source area is in the highlands of Ethiopia [38], and that the high erosion rates on farm lands not only resulted in low crop yields and poverty, but even changed the hydrology [39].

A water value system that can incorporate these water quality-related costs could more clearly reveal, and justify, the urgency of tackling the root cause of the silt problem.

\subsection{Transboundary Water Management}

A basin-wide water value-flow model that integrates all water values, as was the project that Hoekstra started with his 2001 paper on the Zambezi river basin [13], has obvious merits in the context of transboundary water management and water diplomacy. A properly conceived basin-wide valuation model could identify unexpected benefits achieved by upstream or downstream activities that would add value to the system as a whole, and which could be shared between riparian partners.

Such a model would demonstrate where direct values are generated, and how these direct values depend on water flows from upstream; thus, highlighting the interdependencies in transboundary basins. It could assist in identifying ways to enhance the total value added in shared river basins through joint investment programs and other cooperative deals, in the spirit of "benefit sharing" [40]. It could further compute the distribution of costs and benefits over the riparian countries, assess the degree of equity or inequity of these, and generate ideas on how inequalities can be balanced or compensated [41].

\section{Conclusions}

The above review shows that the water value-flow concept has lots to offer in terms of contemporary challenges. It is fully consistent with the "Five Bellagio Principles on Valuing Water" and the "High Level Panel of Water" published in 2017, and can make significant contributions to the first four principles: consider water's multiple values; conduct all processes to reconcile values in ways that are equitable, 
transparent, and inclusive of multiple values; value and protect all sources of water; and promote education and public awareness. It can even go beyond this, as one of the potential innovations is that it can incorporate precipitationsheds, and thus identify the source areas of rainfall. Moreover, it has great potential of contributing to socio-hydrology. Yet, until now, this innovative and potentially ground breaking concept has been completely ignored by researchers and practitioners in the fields of water resources management and economics.

In conclusion, the value-flow concept is a unique framework for integrated assessment of the value of water within a water resources system or river basin. However, the concept can be further enriched, and here we suggest four areas for further in-depth study.

One important element to be studied further is how to incorporate water quality in the value-flow concept. Hoekstra and Chapagain [42] introduced the Grey Water Footprint that accounted for water pollution in the use of water resources, which was further worked out by Liu and collaborators [43]. In this approach, the impact of pollution was measured in terms of the amount of dilution that it would require to bring the receiving body back to acceptable concentrations of the substance in question. However, it did not translate this into a cost to the water resources system, which could subsequently be included in the water value-flow concept. This is an interesting and highly relevant field of further research.

A second element that is lacking in the value-flow concept is instream benefits, i.e., values created without water being "lost" to the system, including navigation but also many ecosystem goods and services that rely on particular flow regimes or flow dynamics. The benefits of instream uses and the benefits and costs of changes in the dynamics of the flow, i.e., the reduction of overbank flows, the loss of flooding dynamics, or the benefits of flow regulation, would be important to assess and to incorporate in the water value-flow concept.

A third element is the possible incorporation of social, cultural, and spiritual values that have so far not been considered, but which may have very high societal value. This is arguably the most challenging research project, yet urgent, as these more difficult to quantify values are often overlooked (not counted), but it is often the reason why certain developments are spiked or cause social unrest. A key question is whether it is necessary (and possible) to commensurate these different values to the same metric.

Finally, it would be worthwhile to test the feasibility and assess the added value of applying the water value-flow concept to existing case studies in the emerging fields of socio-hydrology (e.g., [44-46]) and water accounting (e.g., [47-49]). We intuit that the value-flow concept could add a dimension to both fields of study, which both focus on how the water system and society are entwined [50], because it is precisely at this interface where the water value-flow concept makes its original contribution.

Author Contributions: Conceptualization, H.H.G.S. and P.v.d.Z.; formal analysis, H.H.G.S. and P.v.d.Z.; and writing, H.H.G.S. and P.v.d.Z. All authors have read and agreed to the published version of the manuscript.

Funding: This research received no external funding.

Acknowledgments: The person who should be acknowledged is Arjen Hoekstra, who was the first person to study the value-flow concept with much dedication and energy. The "Value of Water Research Report Series" that he established in 2000, contains 69 items and is testimony of his continued dedication to this important subject. Over the years, the authors have worked closely with Arjen on various aspects of water resources research and owe much to him for the concepts presented in this paper, of which he should have been the first author. This paper can be considered a contribution to the research decade (2013-2022) of IAHS on Panta Rhei. We acknowledge the valuable comments and suggestions of two anonymous reviewers.

Conflicts of Interest: The authors declare no conflict of interest.

\section{References}

1. Lockwood, M. Humans Valuing Nature: Synthesising Insights from Philosophy, Psychology and Economics. Environ. Values 1999, 8, 381-401. [CrossRef]

2. Seymour, E.; Curtis, A.; Pannell, D.; Roberts, A.M.; Allan, C. Same river, different values and why it matters. Ecol. Manag. Restor. 2011, 12, 207-213. [CrossRef] 
3. Green, C. If only life were that simple; optimism and pessimism in economics. Phys. Chem. Earth, Part B: Hydrol. Oceans Atmos. 2000, 25, 205-212. [CrossRef]

4. Savenije, H.; Van Der Zaag, P. Water as an Economic Good and Demand Management, Paradigms with Pitfalls. Water Int. 2002, 27, 98-104. [CrossRef]

5. Hanemann, W.M. The Economic Conception of Water. Chapter 4. In Water Crisis: Myth or Reality; Rogers, P.P., Llamas, M.R., Martinez-Cortina, L., Eds.; Taylor \& Francis: London, UK, 2006; pp. 61-91.

6. Garrick, D.; Hall, J.W.; Dobson, A.; Damania, R.; Grafton, R.Q.; Hope, R.; Hepburn, C.; Bark, R.; Boltz, F.; De Stefano, L.; et al. Valuing water for sustainable development. Science 2017, 358, 1003-1005. [CrossRef]

7. Espeland, W.N.; Stevens, M.L. Commensuration as a Social Process. Annu. Rev. Sociol. 1998, 24, $313-343$. [CrossRef]

8. Nelson Espeland, W. The Struggle for Water-Politics, Rationality and Identity in the American Southwest; The University of Chicago Press: Chicago, IL, USA; London, UK, 1998; 281p.

9. Savenije, H. Why water is not an ordinary economic good, or why the girl is special. Phys. Chem. Earth, Parts A/B/C 2002, 27, 741-744. [CrossRef]

10. Van Der Zaag, P. Asymmetry and Equity in Water Resources Management; Critical Institutional Issues for Southern Africa. Water Resour. Manag. 2007, 21, 1993-2004. [CrossRef]

11. Hellegers, P.; Van Halsema, G. Weighing economic values against societal needs: Questioning the roles of valuing water in practice. Hydrol. Res. 2019, 21, 514-525. [CrossRef]

12. Seyam, I.M.; Hoekstra, A.Y. The Water Value-flow Concept. In Value of Water Research Report Series No. 3; IHE: Delft, The Netherlands, 2000.

13. Hoekstra, A.Y.; Savenije, H.; Chapagain, A. An Integrated Approach Towards Assessing the Value of Water: A Case Study on the Zambezi Basin. Integr. Assess. 2001, 2, 199-208. [CrossRef]

14. Seyam, I.; Hoekstra, A.Y.; Savenije, H. Calculation methods to assess the value of upstream water flows and storage as a function of downstream benefits. Phys. Chem. Earth Parts A/B/C 2002, 27, 977-982. [CrossRef]

15. Seyam, I.; Hoekstra, A.Y.; Savenije, H. The water value-flow concept. Phys. Chem. Earth, Parts A/B/C 2003, 28, 175-182. [CrossRef]

16. Batten, D.F. Can economists value water's multiple benefits? Water Policy. 2007, 9, 345-362. [CrossRef]

17. Tilmant, A.; Kinzelbach, W.; Juízo, D.; Beevers, L.; Senn, D.B.; Casarotto, C. Economic valuation of benefits and costs associated with the coordinated development and management of the Zambezi river basin. Water Policy 2012, 14, 490-508. [CrossRef]

18. Savenije, H.H.G. New definitions for moisture recycling and the relation with land-use changes in the Sahel. J. Hydrol. 1995, 167, 57-78. [CrossRef]

19. Savenije, H. The runoff coefficient as the key to moisture recycling. J. Hydrol. 1996, 176, 219-225. [CrossRef]

20. Van Der Ent, R.J.; Savenije, H.; Steele-Dunne, S.C.; Schaefli, B. Origin and fate of atmospheric moisture over continents. Water Resour. Res. 2010, 46, 12. [CrossRef]

21. Bryson, B. A Short History of Nearly Everything; Random House, Inc.: New York, NY, USA, 2003; 560p.

22. Keys, P.W.; Van Der Ent, R.J.; Gordon, L.J.; Hoff, H.; Nikoli, R.; Savenije, H. Analyzing precipitationsheds to understand the vulnerability of rainfall dependent regions. Biogeosciences 2012, 9, 733-746. [CrossRef]

23. Sivapalan, M.; Savenije, H.; Blöschl, G. Socio-hydrology: A new science of people and water. Hydrol. Process. 2012, 26, 1270-1276. [CrossRef]

24. Karimi, P.; Bastiaanssen, W.G.M.; Molden, D. Water Accounting Plus (WA+) -A water accounting procedure for complex river basins based on satellite measurements. Hydrol. Earth Syst. Sci. 2013, 17, 2459-2472. [CrossRef]

25. Montanari, A.; Young, G.; Savenije, H.; Hughes, D.; Wagener, W.; Ren, L.; Koutsoyiannis, D.; Cudennec, C.; Toth, E.; Grimaldi, S.; et al. "Panta Rhei-Everything Flows": Change in hydrology and society—The IAHS Scientific Decade 2013-2022. Hydrol. Sci. J. 2013, 58, 1256-1275. [CrossRef]

26. Brouwer, R.; Hofkes, M.W. Integrated hydro-economic modelling: Approaches, key issues and future research directions. Ecol. Econ. 2008, 66, 16-22. [CrossRef]

27. Falkenmark, M.; Lannerstad, M. Consumptive water use to feed humanity-Curing a blind spot. Hydrol. Earth Syst. Sci. 2005, 9, 15-28. [CrossRef]

28. Rockström, J.; Falkenmark, M.; Allan, T.; Folke, C.; Gordon, L.J.; Jägerskog, A.; Kummu, M.; Lannerstad, M.; Meybeck, M.; Molden, D.; et al. The unfolding water drama in the Anthropocene: Towards a resilience based perspective on water for global sustainability. Ecohydrology 2014, 7, 1249-1261. [CrossRef] 
29. Bossio, D.; Jewitt, G.P.W.; Van Der Zaag, P. Smallholder system innovation for integrated watershed management in Sub-Saharan Africa. Agric. Water Manag. 2011, 98, 1683-1686. [CrossRef]

30. Makurira, H.; Savenije, H.; Uhlenbrook, S.; Rockström, J.; Senzanje, A. The effect of system innovations on water productivity in subsistence rainfed agricultural systems in semi-arid Tanzania. Agric. Water Manag. 2011, 98, 1696-1703. [CrossRef]

31. Wunder, S. Revisiting the concept of payments for environmental services. Ecol. Econ. 2015, 117, $234-243$. [CrossRef]

32. Fanaian, S.; Graas, S.; Jiang, Y.; Van Der Zaag, P. An ecological economic assessment of flow regimes in a hydropower dominated river basin: The case of the lower Zambezi River, Mozambique. Sci. Total. Environ. 2015, 505, 464-473. [CrossRef]

33. Smit, H.; Kassa, R.M.; Ahlers, R.; van der Zaag, P. The political morphology of drainage-How gully formation links to State formation in the Choke Mountains of Ethiopia. World Dev. 2017, 98, 231-244. [CrossRef]

34. Ali, Y.S.; Crosato, A.; Mohamed, Y.A.; Abdalla, S.H.; Wright, N. Sediment balances in the Blue Nile River Basin. Int. J. Sediment Res. 2014, 29, 316-328. [CrossRef]

35. Omer, A.Y.A.; Ali, Y.S.A.; Roelvink, D.; Dastgheib, A.; Paron, P.; Crosato, A. Modelling of sedimentation processes inside Roseires Reservoir (Sudan). Earth Surf. Dyn. 2015, 3, 223-238. [CrossRef]

36. Osman, I.S.; Schultz, B.; Osman, A.; Suryadi, F.X. Simulation of Fine Sediment Transport in Irrigation Canals of the Gezira Scheme with the Numerical Model FSEDT. J. Irrig. Drain. Eng. 2016, 142, 04016049. [CrossRef]

37. Temesgen, M.; Uhlenbrook, S.; Simane, B.; Van Der Zaag, P.; Mohamed, Y.; Wenninger, J.; Savenije, H. Impacts of conservation tillage on the hydrological and agronomic performance of Fanya juus in the upper Blue Nile (Abbay) river basin. Hydrol. Earth Syst. Sci. 2012, 16, 4725-4735. [CrossRef]

38. Ali, Y.S.A.; Paron, P.; Crosato, A.; Mohamed, Y.A. Transboundary sediment transfer from source to sink using a mineralogical analysis. Case study: Roseires Reservoir, Blue Nile, Sudan. Int. J. River Basin Manag. 2017, 16, 477-491. [CrossRef]

39. Gebremicael, T.G.; Mohamed, Y.; Betrie, G.; Van Der Zaag, P.; Teferi, E. Trend analysis of runoff and sediment fluxes in the Upper Blue Nile basin: A combined analysis of statistical tests, physically-based models and landuse maps. J. Hydrol. 2013, 482, 57-68. [CrossRef]

40. Sadoff, C.W. Beyond the river: The benefits of cooperation on international rivers. Water Policy 2002, 4 , 389-403. [CrossRef]

41. Van Der Zaag, P.; Seyam, I.; Savenije, H. Towards measurable criteria for the equitable sharing of international water resources. Hydrol. Res. 2002, 4, 19-32. [CrossRef]

42. Hoekstra, A.Y.; Chapagain, A.K. Globalization of Water: Sharing the Planet's Freshwater Resources; Blackwell Publishing: Oxford, UK, 2008.

43. Liu, C.; Kroeze, C.; Hoekstra, A.Y.; Gerbens-Leenes, W. Past and future trends in grey water footprints of anthropogenic nitrogen and phosphorus inputs to major world rivers. Ecol. Indic. 2012, 18, 42-49. [CrossRef]

44. Elshafei, Y.; Sivapalan, M.; Tonts, M.; Hipsey, M.R. A prototype framework for models of socio-hydrology: Identification of key feedback loops and parameterisation approach. Hydrol. Earth Syst. Sci. 2014, 18, 2141-2166. [CrossRef]

45. Kandasamy, J.; Sounthararajah, D.; Sivabalan, P.; Chanan, A.; Vigneswaran, S.; Sivapalan, M. Socio-hydrologic drivers of the pendulum swing between agricultural development and environmental health: A case study from Murrumbidgee River basin, Australia. Hydrol. Earth Syst. Sci. 2014, 18, 1027-1041. [CrossRef]

46. Van Emmerik, T.; Li, Z.; Sivapalan, M.; Pande, S.; Kandasamy, J.; Savenije, H.; Chanan, A.; Vigneswaran, S. Socio-hydrologic modeling to understand and mediate the competition for water between agriculture development and environmental health: Murrumbidgee River basin, Australia. Hydrol. Earth Syst. Sci. 2014, 18, 4239-4259. [CrossRef]

47. Karimi, P.; Bastiaanssen, W.G.M.; Molden, D.; Cheema, M.J.M. Basin-wide water accounting based on remote sensing data: An application for the Indus Basin. Hydrol. Earth Syst. Sci. 2013, 17, 2473-2486. [CrossRef]

48. Karimi, P.; Bastiaanssen, W.G.M. Spatial evapotranspiration, rainfall and land use data in water accounting-Part 1: Review of the accuracy of the remote sensing data. Hydrol. Earth Syst. Sci. 2015, 19, 507-532. [CrossRef] 
49. Karimi, P.; Bastiaanssen, W.G.M.; Sood, A.; Hoogeveen, J.; Peiser, L.; Bastidas-Obando, E.; Dost, R.J. Spatial evapotranspiration, rainfall and land use data in water accounting-Part 2: Reliability of water acounting results for policy decisions in the Awash Basin. Hydrol. Earth Syst. Sci. 2015, 19, 533-550. [CrossRef]

50. Savenije, H.; Hoekstra, A.Y.; Van Der Zaag, P. Evolving water science in the Anthropocene. Hydrol. Earth Syst. Sci. 2014, 18, 319-332. [CrossRef]

(C) 2020 by the authors. Licensee MDPI, Basel, Switzerland. This article is an open access article distributed under the terms and conditions of the Creative Commons Attribution (CC BY) license (http://creativecommons.org/licenses/by/4.0/). 